2 Cordero AS, Bonner JT, Brynes RK. AIDS and the anaesthetist. Can Anaesth Soc J 1985; 32: 45-8.

3 Greene $E R$. Acquircd immunodefficiency syndrome: an overview for anesthesiologists. Anesth Analg 1986; 65: 1054-8.

4 Lee KG. SoniN. AIDS and anaesthesia. Anaesthesia 1986; 41: $1011-16$

5 Feorino PM, Jaffe HW, Palmer E et al. Transfusion associared acquired immunodeficienc y syndrome: evidence for persistent infection in blood donors. N Engl J Med 1985; 312: $1293-6$.

6 Maloney MJ, Cox F, Wray BB, Guill MF, HaglerJ. AlDS in a child $5 \frac{1}{2}$ years after transfusion. N Engl J Med 1985; 312: 1256-7.

7 Curran JW. The epidemiology and prevention of acquired immunodeficiency syndrome. Ann Int Med 1985; 103: $657-62$.

8 Schorr JB, Berkowizz A, Cumming PD, Katz AJ, Sandler $S G$. Prevalence of HTLV-III in American blood donors. N Engl J Med 1985; 313: 384-5

9 AIDS and Health Care Workers. Ministry of Health, Toronto, Ontario, Canada, Fall 1986.

10 Update: Human immunodeficiency virus infections in health-care workers exposed to blood of infected patients United States. Canada Diseases Weekdy Report. Hcalth and Welfare Canada, May 30, 1987; 95-8.

11 Sumurary: recommendations for preventing transmission of infection with hunan T-lymphotropic virus type IIL lymphadenopathy-associated vins in the workplace. Atlanta. Georgia: Center for Disease Control; MMWR $1985 ; 254: 3162-7$.

12 Arden $J$. Anesthetic management of patients with AIDS. Anesthesiology 1986; 64: 660-1.

13 Minkoff HL, Schwarz RH. AIDS: Time for obstetricians to get involved. Obstet Gynecol 1986; 68: 267-8.

14 Quaggin A. Get prepared for more cases of AIDS during pregnancy, Can Med Assoc J 1987; 136: 192-3.

15 Scon GB, Fischl MA, Klimas $N$ et ai. Mothers of infants with acquired immunodeficiency syndrome. JAMA 1985 252: 363-6.

16 Weber DS, Redfield RR, Leman SM. Acquired immunodcficiency syndrome: epidemiology and significance for the obstetrician and gynecologist. Obstet Gynecol 1986; 155: 235-40.

17 Ho DM. Pomerantz RJ, Kaplan JC. Pathogenesis of infection with human immunodeficiency virus. $N$ Engl $J$ Med 1987; 317: 278-86.

18 Greene ER. Spinal and epidural anesthesia in patients wilh acquired immunodefieiency syndrome. Anesth Analg 1986; 65: 1089-93.

19 Pritchard JA, MaCDonald PC, Gant NF. Medical and surgical illnesses during pregnancy and the puerperium. In: Williams Obstetrics, 17 th edition. Connecticut:
Appleton-Century Crofts, 1985: 614-5.

20 Maze $M$, Baden JM. Anesthesia for patients with liver disease. In: Miller RD (Ed). Anesthesia, 2nd edition. New York: Churchill Liwingstone Inc, 1986: 1665-80.

21 Douvas SF, Meeks GR, Philips $J$ et al. Liver disease in pregnancy. Obstet and Gynccol Survey 1983; 38:53 J-6.

22 Mathieu A Dienstag JL. The hazard of viral hepatitis to anesthesiologists and other operating room rersonncl. $n$ : Orkin FK, Connernan LH (Eds). Complications in Anesthesiology. Philadelphia: JB Lippincott, 1983: 697-705.

23 Roizen $M F$. Anesthetic implications of concurrent diseases. In: Miller RD (Ed). Anesthesia, 2nd edition. New York: Churchill Livingstone Inc, 1986: 317-19.

24 Schemel $W H$. Unexpected hepatic dysfunction found by multiple laboratory screening. Anesth Analg 1976; 55: 810-2.

\title{
Herpes virus infections of pregnancy
}

The Herpes viruses include the cytomegalovirus (CMV), Epstein-Bart virus (EB), herpes simplex virus and Varicella-Zoster-virus (VZV).' These agents infect almost all humans at some point during their lives, the age of acquisition varying among populations. The herpes viruses are unique in that viral shedding may persist for weeks or months after the primary event. Latent infection is established after the primary infection and subsequently reactivation may occur, frequently subclinical. The major importance of the herpes viruses to the obstetric patient lies in their potential to infect the fetus or newborn resulting in either death or permanent neurological sequelae. Concerns about maternal well-being include systemic infection and complaints with medico-legal implications.

Some definitions which are helpful in understanding the literature regarding viruses are: primary infection the first exposure to the virus. Latent infection - the virus remains dormant in a host cell. Reactivation - reawakening of virus in the latent state to produce identifiable, infectious particles; this occurs spontaneously or as a result of external stimuli. Recrudescence - reactivation in the sensory ganglion to produce a skin or mucous mernbrane lesion in the corresponding dermatome. Recurrence - the presence of the infectious virus in the peripheral tissue but without a clinical lesion (e.g., viral shedding) ${ }^{2}$ 


\section{CMV and E-B virus}

CMV is the most common virus to be transmitted in utero (0.2-2.2 per cent among live births). Primary maternal CMV infection is usually asymptomatic but has a resulting fetal infection rate of approximately 40 per cent. Mortality among congenitally infected infants is $20-40$ per cent. Neurological problems are the main concern in those infants who survive. Primary E-B virus infection is rare during pregnancy, as the number of susceptible females is small (most have antibodies). ${ }^{\prime}$ Although both thc CMV and $E-B$ virus have potential serious effects on the newborn, they pose little threat to the mother. As such, they have minimal anaesthetic implications.

\section{Varicella-Zoster-Virus}

Maternal varicella (chickenpox) in the immediate peripartum period may produce congenital chickenpox which carries a mortality of 20 per cent. The use of zoster immunoglobulin in combination with antiviral agents holds some promise in reducing this mortality rate. ${ }^{3}$ Maternal complications from varicella have the same incidence as in the nonpregnant population. Herpes zoster (shingles) has not been implicated as a cause of either fetal or maternal death during pregnancy. It occurs more frequently in the older and immunocompromized populations. However, spinal anaesthesia has been reported by Vandam ${ }^{4}$ to lead to VZV recrudescence.

\section{Herpes simplex}

Until recently, the major concerns about anaesthesia in the obstetric patient with herpes have been with respect to the herpes simplex virus. This virus has two serological subtypes, I and II. Type I (herpes labialis, cold sore, HSV-I) typically infects the face and oral area, while type II (herpes genitalis, HSV-II) infects the genital area. Each can, however, infect either area.

As with the other herpes viruses, herpes simplex can establish latent infections, the preferrcd site being neuronal cells. After primary infection, the virus spreads from the periphery to the sensory ganglion by intra-axonal transport. On reaching the ganglion, an interaction between the "target cell" and the infecting virus is required to establish latency. The virus may then lie dormant in the sensory ganglion. ${ }^{5}$ Reactivation of the virus may later show itself as a skin or mucous membrane lesion in the appropriate dermatome.

Primary infection wilh Type I occurs during childhood; about 90 per cent of the population have antibodies by age 18. In common with the other herpes viruses, asymptomatic shedding is common, as is recrudescence. Recently, concems $^{6,7}$ have been raised with respect to recrudescence when epidural anaesthesia has been used for
Caesarean section, followed by epidural morphine for postoperative analgesia. However, a good prospective study has not yet confirmed this observation. In 1984 a report from Romania by $\operatorname{Cardan}^{8}$ described the use of spinal morphine for enuresis in children. He noted development of herpes labialis one day after the procedure.

Genital herpes (HVS-II) has reached epidemic proportions, with 20-60 per cent of adults now thought to be infected. The course of primary infection can range from asymptomatic to a severe, systemic illness with fever, myalgia, arthralgia, lymphadenopathy, and local lesions which shed large quantities of virus. Due to this variability, it is often difficult to ascertain if the infection is primary. Eight per cent of patients with primary intection will develop aseptic meningitis, fortunately with few neuorological sequelae, although two per cent of patients exhibit sacral nerve dysfunction. ${ }^{9}$

Transmission of the virus to the fetus or neonate at the time of delivery is possible from either recurrence (asymptomatic viral shedding) or recrudescence (presence of a visible lesion plus shedding). ${ }^{10}$ As a result, repeated cultures for HSV-Il are taken from 34 weeks gestation (when a previous history exists) and Caesarean delivery performed when cultures are positive or if lesions are visible. The risk to the neonate of infection following exposure at delivery to recurrent/recrudescent herpes genitalis has been calculated to be less than eight per cent. "If there is a primary infection, the risk is likely to be substantially higher.

For the obstetric patient with HSV-II, possible dissemination of infection with resulting maternal meningitis and/or cncephalitis following rcgional anaesthesia has led to debate regarding its use in these patients. A 1983 survey of anaesthetists in North America, by the Society for Obstetric Anesthesia and Perinatology, ${ }^{12}$ revealnd the majority favoured epidural anaesthesia in the case of recurrentirecrudescent HSV-II. However, one-third would not administer an epidural in the presence of an active lesion, especially a primary infection. Ramanathan et $a .^{13}$ reported a retrospective series of 43 patients who received epidural anaesthesia and 28 who underwent general anaesthesia for Caesarean section because of recurrent HSV-Il. Both techniques were shown to be safe. Ravindran et al. ${ }^{14}$ reported 30 patients who received epidural anaesthesia, also without complication, although the authors did not indicate if any patient had a primary infection. To date, there have been no reports of central nervous system complications secondary to regional anaesthesia in this group of patjents. Many patients have undoubtedly received regional anaesthesia at a time when they were experiencing asymptomatic, unrecognized, viral shedding and these cases, too, have been without reported incident. 
Concerms to be weighed in the selection of an anaesthetic technique for patients with HSV-Ш include:

1 Patient wishes. These patients frequently have psychological stress and would prefer a regional technique, in order to participate in the birth experience.

2 Medico-legal concerns. There is a known association of aseptic meningitis and sacral nerve dysfunction with primary HSV-II infection. The presence of these postoperatively may lead to the technique and the anaesthetist being held responsible. Therefore, if a patient has primary HSV-II infection, the risk of these sequelae should be included in the discussion to obtain informed consent.

3 General anaesthesia. This technique is not without theoretical risk of exacerbating HSV-II infection as it is known that anaesthesia may cause immunocompromise.

Present evidence points to the safety of epidural anaesthesia in patients with recurrent/recrudescent HSVII infection. The presence of lesions at the epidural site would be a contraindication, as would patient refusal. Where primary infection is present, along with systemic symptoms (fever, headache, myalgia), caution should be exercised. Many anaesthetists think that a regional technique is contraindicated in these patients, although data to support their concerns is lacking. Informed consent is essential when a patient has primary HSV-ll. As well, it is important to remember that normal infcction control measures are necessary, in the case of both HSV-I and HSV-Il infections, to prevent spread to the neonate. The potential risk to the newborn, although low statistically, is devastating.

\section{References}

1 Stagno $S$, Whitley $R J$. Herpes yirus infections of pregnancy - Parts I and II. N Engl J Med 1985; 313: 1270-4 and $1327-30$.

2 Wildy $P$, Field $H J$, Nash $A A$. Classical herpes latency revisited. Symp Soc Gen Microb 1982; 33: 133-67.

3 Carter $P E$, Duffy $P$, Lloyd DJ. Neonatal varicella infection (letter). Lancet 1986; ii: 1459-60.

4 Vandam $L D$. Complications of spinal and cpidural anesthesia. In: Orkin FK, Cooperman LH (Eds). Complications in Anaesthesiology. Philadelphia: JB Lippincott, 1983: 75-105.

5 Kristensson $K$, Lycke E, Sjostrand J. Spread of Herpes simplex virus in peripheral nerves. Acta Neuropathol 1971; 17: 44-53.
6 Crone L, Clark K, Albrition W, Crank S, Rea L, Tan L Relation between oral Herpes simplex and the use of epidural morphine in obstetric patients. Society for Obsterric Anesthesia and Perinatology. Scientific abstract. Salt Lake City, May 1986, 124.

7 Douglas MJ, Thomas EE. MCMorland GH, Anderson J, Cairns $G$. Epidemiology of HSV-I infection in the puerperal population - does epidusal morphine cause recrudescence? Society for Obstetric Anesthesia and Perinatology. Scientfic abstract. Salt Lake City, May 1985, 125.

8 Cardan E. Herpes simplex after spinal morphine. Anaesthesia 1984; 39: 1031.

9 Belshe RB (Ed). Textbook of Human Virology. Massachusetts: PSG Publishing Co Inc, 1984: 814-27.

10 Whitley $R J$, Nahmias $A J$, Visinine $A M$, Fleming $C L$. Alford $C A$. The natural history of Herpes simplex virus infection of mother and newborn. Pediatrics 1980; 66: 439-94.

11 Prober CG, Sullender WM, Yasukawa $L L, A u D S$, Yeager AS. Arvin AM. Low risk of Herpes simplex virus infections in neonates exposed to the virus at the time of vaginal delivery to mothers with recurrent genitil herpes infections. N Engl J Med 1987; 316: 240-4.

12 Joyce TH, Marx GF. Regional anesthesia and herpes. Society for Obstetric Anesthesia and Perinatology Newsletter 1984; 14: 1 .

13 Ramanattan $S$, Sheth $R$, Turndorf $H$. Anesthesia for caesarean section in paticnts with genital herpes infections: a retrospective study. Anesthesiology 1986; 64: 807-9.

14 Ravindran RS, Gupta CD, Stoops CA. Epidural analgesia in the presence of Herpes simplex virus (type 2 ) infection. Anesth Analg 1982; 61: 714-5. 